\title{
New records of Caribbomerus from Hispaniola and Dominica with redescription of $C$. elongatus (Fisher) and a key to species of the genus in the West Indies (Coleoptera, Cerambycidae, Cerambycinae, Graciliini)
}

\author{
Steven W. Lingafelter \\ Systematic Entomology Laboratory, Plant Sciences Institute, Agriculture Research Service, U.S. Department of \\ Agriculture, National Museum of Natural History, Washington, D.C. 20013-7012, U.S.A. \\ Corresponding author: Steven W. Lingafelter (steve.lingafelter@ars.usda.gov) \\ Academic editor: A. Konstantinov| Received 20 December 2010 | Accepted 23 February 2011 | Published 11 March 2011 \\ Citation: Lingafelter SW (2011) New records of Caribbomerus from Hispaniola and Dominica with redescription of \\ C. elongatus (Fisher) and a key to species of the genus in the West Indies (Coleoptera, Cerambycidae, Cerambycinae, \\ Graciliini). ZooKeys 85: 27-39. doi: 10.3897/zookeys.85.826
}

\begin{abstract}
Three species of Caribbomerus Vitali are newly recorded for the Dominican Republic: C. decoratus (Zayas), C. elongatus (Fisher), and C. asperatus (Fisher). The first two also represent first records for Hispaniola. Caribbomerus elongatus (Fisher) is redescribed based on additional material, including the first known males. Caribbomerus similis (Fisher) is newly recorded for Dominica. A key to the species of the genus from the West Indies is provided.
\end{abstract}

\section{Keywords}

Dominican Republic, Haiti, longhorned woodboring beetles, taxonomy, faunistics

\section{Introduction}

Only one genus of Graciliini occurs in the West Indies, Caribbomerus Vitali (formerly known under the preoccupied Merostenus Walker and formerly placed in the Callidiopini) (Vitali and Rezbanyai-Reser 2003; Monné and Bezark 2010). Caribbomerus is most easily recognized by the following combination of characters: long, narrow body (4-11 mm long; 0.7-1.9 mm wide); elongate, usually parallel-sided elytra (elytron length 5-9 times its width); anterior coxal cavities closed posteriorly by a procoxal process which is extremely narrow between the procoxae and then abruptly widened 
behind; coarsely faceted eyes; and antennae distinctly longer than body (in part, based on Martins and Galileo 2005). Other characters include: third antennomere distinctly shorter than all others (with exception of pedicel); elytral apex of most species impunctate and with integument smooth and distinctly paler than remainder; prothorax $0.16-0.25$ length of body and widest at or near posterior third in most species.

Prior to Napp and Martins (1984), Caribbomerus was known only from the Antilles. With the species they described from Brazil, Mexico, and Jamaica, along with a species Micheli (2003) described from Puerto Rico, the number of species was increased to twelve.

Three species of Caribbomerus: C. decoratus (Zayas), C. elongatus (Fisher), and C. asperatus (Fisher) are recorded from the Dominican Republic (new country records) (unrecorded in Monné and Bezark 2010; Perez-Gelabert 2008). For the first two, Hispaniola represents a new island record. Caribbomerus elongatus is redescribed based on additional material (including newly discovered males) revealing broader morphological variation than reflected in the original description. All Hispaniolan Caribbomerus are restricted to the southern and southwestern parts of the Dominican Republic, along and southwest of the Cordillera Central (Fig 6). A key, table of measurements (Table 1), and photos (Figs 1-5) to all the species of Caribbomerus from the West Indies are provided.

\section{Methods}

Most of the material examined in this study was collected by R. H. Turnbow, Jr. (RHTC), E. F. Giesbert (FSCA), J. Rawlins and R. Davidson (CMNH), and M. Ivie and K. Guerrero (WIBF). Holotypes are deposited in the Smithsonian Institution (USNM) and images are available in the online Smithsonian Primary Type database (Lingafelter et al. 2010).

Images were captured with a Zeiss AxioCam HRc camera mounted on a Zeiss Discovery V20 stereomicroscope with Sycop motorized zoom and focus control. Objectives used included a PlanApo S 1.0× and 0.63×. For illumination, a Zeiss KL 2500 LCD with ring light attachment was used. Axiovision software enabled preparation of montaged images and precise, automatically calibrated measurements.

In the course of this work, these collections and others were examined for Caribbomerus specimens. Nearns et al. (2006) was consulted for species in the Fernando Zayas collection as well as the online type image databases of the Museum of Comparative Zoology, Harvard University (MCZC 2010), and the American Museum of Natural History (AMNH 2010). The acronyms and contact persons are listed below:

BMNH The Natural History Museum, London, England (Sharon Shute, Max Barclay)

CMNH Carnegie Museum of Natural History, Pittsburgh, Pennsylvania, U.S.A. (J. Rawlins, R. Davidson, R. Androw) 
CNCI The Canadian National Collection of Insects, Ottawa, Ontario, Canada (S. Laplante, O. Lonsdale)

EFGC Edmund F. Giesbert Collection (at FSCA), Gainesville, Florida, U.S.A. (M. Thomas, P. Skelley)

FSCA Florida State Collection of Arthropods, Gainesville, Florida, U.S.A. (M. Thomas, P. Skelley)

FSPC Frederick W. Skillman Private Collection, Pearce, Arizona, U.S.A. (F. W. Skillman)

RHTC Robert H. Turnbow, Jr. Private Collection, Ft. Rucker, Alabama, U.S.A. (R. H. Turnbow)

USNM National Museum of Natural History, Smithsonian Institution, Washington, DC, U.S.A. (S. Lingafelter)

WIBF West Indian Beetle Fauna Project, Bozeman, Montana, U.S.A. (M. Ivie)

\section{Caribbomerus elongatus (Fisher)}

Figs 1-4, 5a,f, 6, Table 1

Diagnosis. Based on the availability of additional non-type material (including males), the variation within this species can now be more fully documented. Although the holotype female has uniformly pale testaceous antennae, the antennae of males are narrowly dark annulate at the apices of most antennomeres (except scape and pedicel). The pronotum of females is slightly swollen posteriorly and then moderately constricted at the base but in males it is nearly parallel-sided and not or barely wider at posterior third unlike most of the remaining species of the genus. The pronotum of both sexes is densely punctate throughout, but in some females there is a very small, vaguely defined median callus lacking punctures and surrounded by a slight depression. The pronotum and elytra have a coating of tawny, appressed pubescence which does not obscure punctures. The elytral apices are abruptly smooth and impunctate with the anterior margin of this region slightly depressed.

Redescription. Small size, 6.63-7.99 mm long; 1.19-1.82 mm broad; integument reddish-brown, with pronotum, head, and base of elytra slightly darker. Head with sparse, tawny pubescence not obscuring punctation; sparsely but distinctly punctate. Eye lobe coarsely faceted; completely, widely separated; strongly protuberant laterally (nearly projecting as wide as humeri;) lower lobe occupying nearly all of head from lateral view; upper lobe much smaller; lobes connected by 5 facets at narrowest point; broadly separated by two-thirds width of pronotum on vertex behind antennal tubercles. Interantennal impression very deep with antennal tubercles strongly elevated in V-shape. Antennae of males extending approximately $1.5 \times$ length of body in males, $1.3 \times$ length of body in females; covered with fine, inconspicuous, short, translucent pubescence. Antennomeres 3-11 of males noticeably dark brown at extreme apices, otherwise, pale brown (antennomeres uniformly pale testaceous in females). Scape extending beyond anterior pronotal margin; integument smooth, 

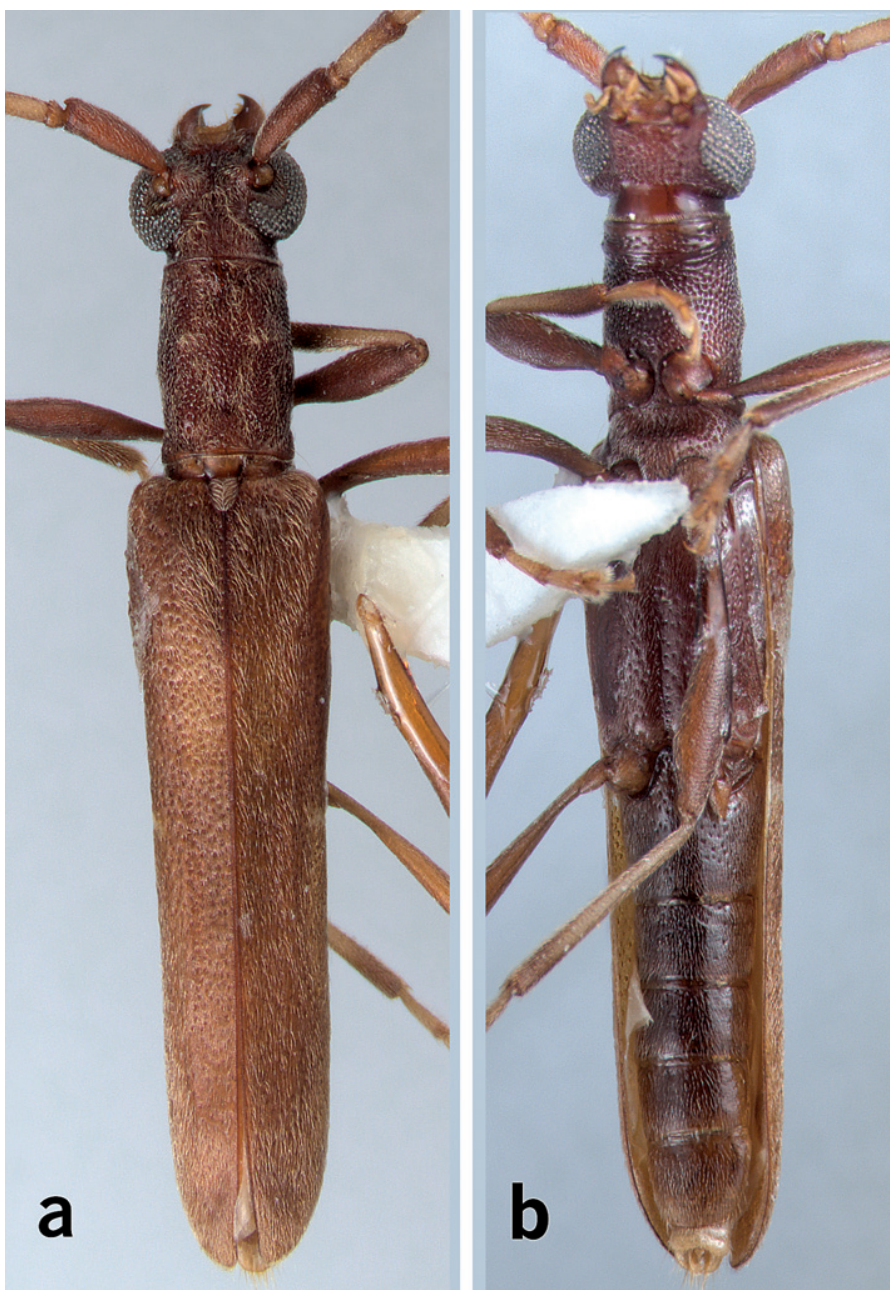

Figure I. Habitus montage images of Caribbomerus elongatus (Fisher), male. a Dorsal b ventral.

not asperate. Other than antennomere 2, antennomere 3 shortest; remaining antennomeres successively increasing in length to 9; 9-11 subequal. Antennomere lengths as follows: scape: $0.59-0.95 \mathrm{~mm}$; antennomere 3: $0.42-0.69 \mathrm{~mm}$; antennomere 4: 0.75-1.14 mm; antennomere 5: 0.95-1.48 mm; antennomere 6: $1.21-1.86 \mathrm{~mm}$. Pronotum distinctly longer than broad, cylindrical in male; distinctly narrower than elytral base (in female, less cylindrical, slightly swollen at posterior third); sparsely, tawny pubescent; distinctly punctate, but punctures small and non-contiguous; without distinct calli, but with small anterior and posterior depressions in male (female with small, vague middle callus surrounded by depression on pronotal disk). Pronotal length: 1.19-1.57 mm; pronotal width: 0.78-1.13 mm; pronotal length/width: 1.3-1.6. Pronotum about $0.18-0.19 \times$ length of body. Prosternum sparsely pubescent; densely, closely punctate. Elytron pale reddish brown, slightly darker at base 
Table I. Anatomical measurements (in millimeters) and proportions in West Indian Caribbomerus species. $\mathbf{B L}=$ body length; $\mathbf{E L}=$ elytron length; $\mathbf{E W}=$ elytron width; $\mathbf{P L}=$ pronotum length; $\mathbf{P W}=$ pronotum width.

\begin{tabular}{l|c|c|c|c|c|c|c|c}
\hline Taxon & $\mathbf{B L}$ & $\mathbf{E L}$ & $\mathbf{E W}$ & $\mathbf{P L}$ & $\mathbf{P W}$ & $\mathbf{B L} / \mathbf{P L}$ & $\mathbf{E L} / \mathbf{E W}$ & PL/PW \\
\hline asperatus & $4.27-6.53$ & $2.50-3.73$ & $0.46-0.78$ & $0.94-1.61$ & $0.78-1.32$ & $4.5-5.6$ & $4.8-5.4$ & 1.2 \\
\hline attenuatus & $4.08-5.38^{1}$ & $2.67-3.52$ & $0.46-0.56$ & $0.84-1.26$ & $0.74-0.90$ & $4.3-4.9$ & $5.8-6.3$ & $1.1-1.4$ \\
\hline charynae & 5.81 & 3.71 & 0.53 & 1.05 & 0.88 & 5.53 & 7.0 & 1.1 \\
\hline decoratus & $5.11^{2}-5.68$ & $3.47-3.79$ & $0.50-0.52$ & $0.98-1.22$ & $0.73-0.80$ & $4.6-5.2$ & $6.9-7.3$ & $1.3-1.5$ \\
\hline elongatus & $6.63^{3}-7.99$ & $4.62-5.49$ & $0.49-0.76$ & $1.19-1.57$ & $0.78-1.13$ & $5.1-5.6$ & $7.2-9.4$ & $1.3-1.6$ \\
\hline exiguus & $5.61^{4}$ & 3.36 & 0.56 & 1.32 & 0.81 & 4.2 & 6.0 & 1.6 \\
\hline picturatus & $4.4-4.5$ & $2.8-2.9$ & $0.40-0.45$ & 1.00 & $0.60-0.65$ & 4.4 & $6.4-7.0$ & 1.6 \\
\hline productus & $4.5-10.0$ & 6.92 & 0.86 & 1.88 & 1.42 & 5.3 & 8.0 & 1.3 \\
\hline similis & $5.92^{5}$ & 3.78 & 0.54 & 1.18 & 0.99 & 5.0 & 7.0 & 1.1 \\
\hline
\end{tabular}

Zayas (1975) reports on specimens from Cuba as large as $6.5 \mathrm{~mm}$ (outside the range I have seen). Zayas (1975) reports the holotype as $4.5 \mathrm{~mm}$ (outside the range I have seen from Hispaniola).

Zayas (1975) reports a specimen as small as $5.5 \mathrm{~mm}$ (outside the range I have seen from Hispaniola).

4 Zayas (1975) reports a specimen as small as $4.0 \mathrm{~mm}$.

5 Chalumeau and Touroult (2005) reports this species as large as $6.8 \mathrm{~mm}$.

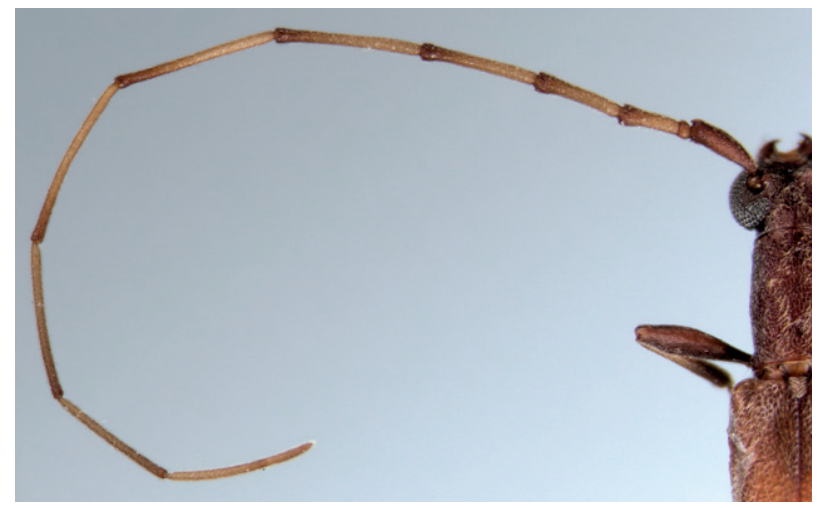

Figure 2. Antenna of Caribbomerus elongatus (Fisher) male.

(with vague, darker areas at humerus, middle, and apical third in a few specimens); distinctly but separately punctate; punctures becoming slightly sparser posteriorly and then abruptly disappearing from apices; anterior margin of impunctate apices slightly depressed; sparsely tawny pubescent (pubescence becoming denser at apices); very long and narrow, narrowly rounded at apices. Elytron length: 4.62-5.49 mm; elytron width: 0.49-0.76 mm; elytral length/width: 7.2-9.4. Scutellum sparsely tawny pubescent; setae joining together and at middle; rounded posteriorly; not noticeably punctate. Hind Leg moderately long, but femur not attaining abdominal apex; reddish brown; sparsely covered in short pubescence, only weakly expanded apically. Tibiae (particularly metatibia) narrow, elongate, straight, somewhat darkened apically. Venter sparsely pubescent, darker than dorsum. Abdomen of both sexes with margin of fifth sternite evenly, broadly rounded. 


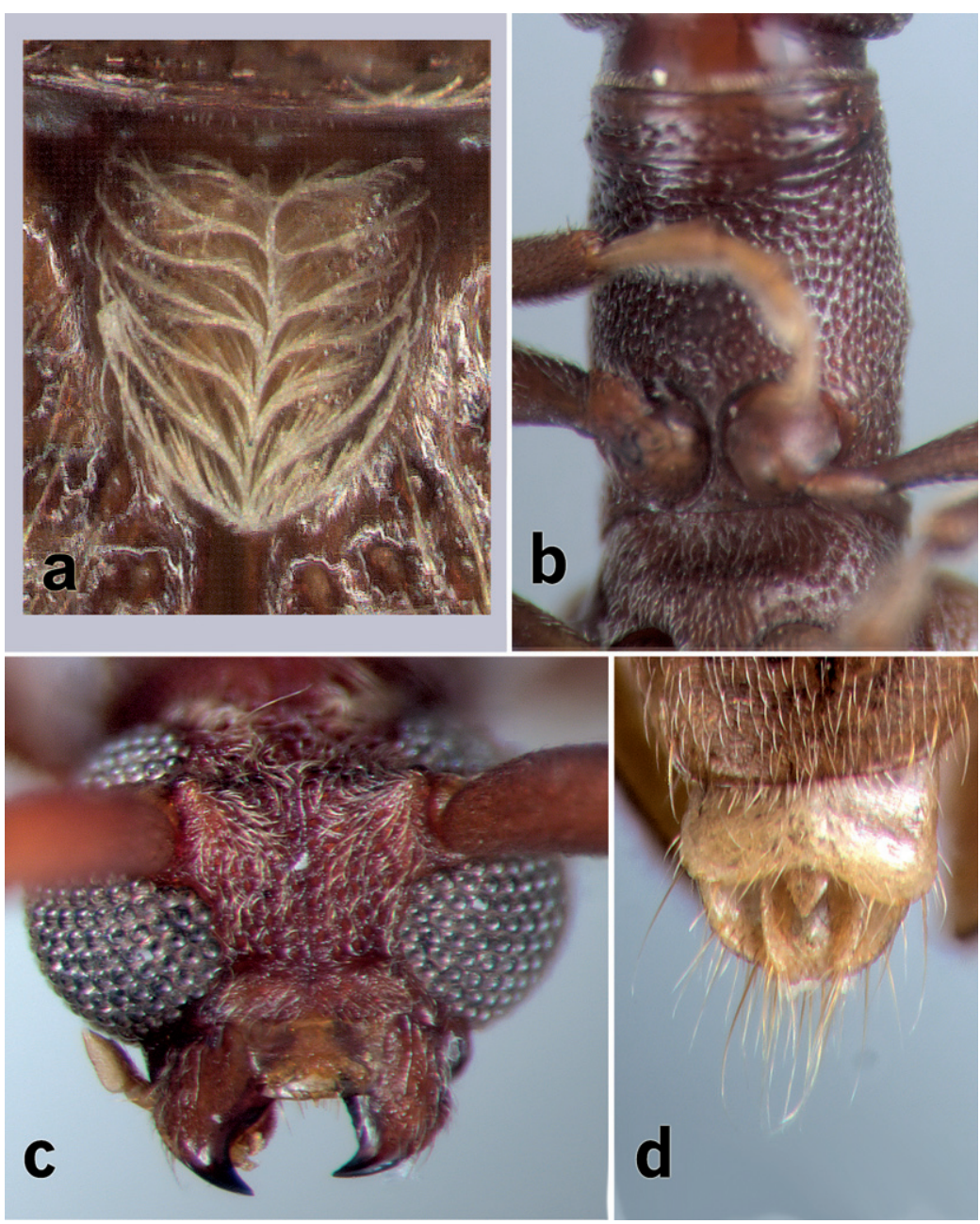

Figure 3. Caribbomerus elongatus (Fisher) male. a Scutellum b Prosternum and mesosternum c head d apex of abdomen showing parameres.

Discussion. Using the key to Caribbomerus of Vitali and Rezbanyai-Reser (2003), this species would run nearest $C$. howdeni (Napp and Martins), a Mexican species, based on the coloration, and shape and pubescence of the pronotum. However, their key is incorrect in coding C. elongatus as having a glabrous pronotum. The holotype of C. elongatus (and all of the new material seen) clearly has translucent pubescence on the pronotum as noted in Fisher's (1932) description. This species, previously known by the female holotype from Cuba (Fisher 1932; Monné and Bezark 2010) and an unspecified number from Oriente, Las Villas, and Pinar del Rio provinces in Cuba as mentioned by Zayas (1975), is now documented for the Dominican Republic (new island \& country record).

Specimens. Holotype (female): Cuba, Wajay, Havana, 15 December, 1930, S. C. Bruner, coll. (USNM). Dominican Republic: San Juan Prov., Sierra de Neiba, trail to Sabana de Silencio, $10 \mathrm{~km}$ SSW of El Cercado, 1650-1700 m, 10-11 July, 2006, A. 


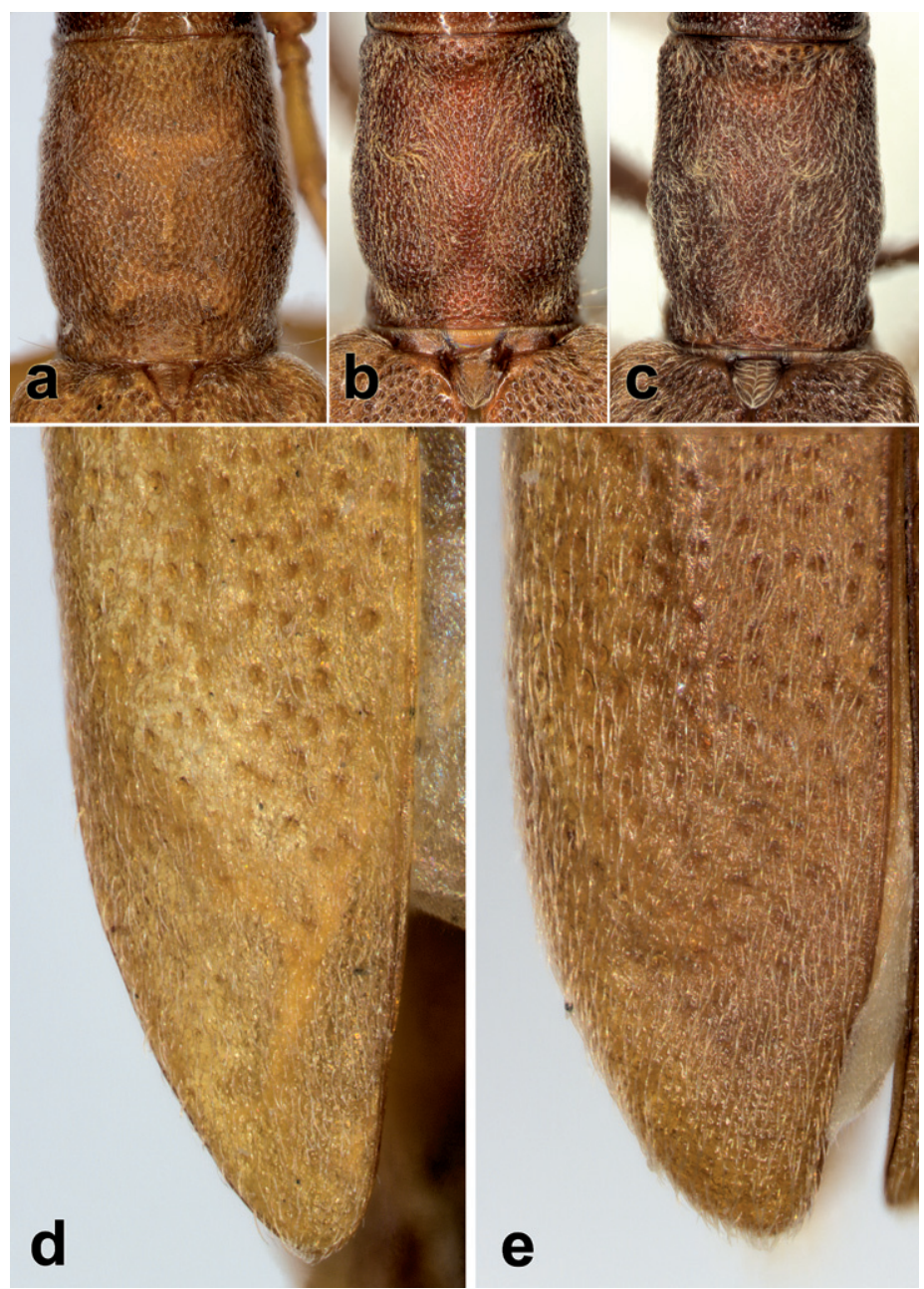

Figure 4. Pronotum. a Caribbomerus elongatus (Fisher) holotype female b C. elongatus (Fisher) female $\mathbf{c} C$. elongatus (Fisher) male. Elytral apex. d C. elongatus (Fisher) holotype female e C. elongatus (Fisher) male.

Konstantinov, coll. $18^{\circ} 39.935^{\prime} \mathrm{N} ; 7^{\circ} 31.964^{\prime} \mathrm{W}$ (1 male, USNM); Dominican Republic: Independencia Prov. P. N. Sierra de Bahoruco around Caseta no. 1, 18¹6.038'N; 71³2.691'W, December 11-12, 2003, D. Perez, R. Bastardo, B. Hierro, RD\#191 (1 male, USNM); Dominican Republic: Independencia, Sierra de Bahoruco, north slope, $13.5 \mathrm{~km}$ SE Puerto Escondido, 18¹2’24”N, 71³0'54”W, 1807 m, 24-26 Mar 2004, R. Davidson, J. Rawlins, C. Young, C. Nuñez, M. Rial, broadleaf Pinus dense woodland, hand collected, Sample 41243 (1 male, CMNH); Dominican Republic: Independencia, Sierra de Bahoruco, Lomo del Toro, 18¹7’16”N, 7142’46”W, 2310 m, 7-8 November 2002, W. A. Zanol, C. W. Young, C. Staresinic, J. Rawlins, meadow in pine woods, hand collected, Sample 40149 (1 female, CMNH); Dominican Republic: Pedernales, 5 km NE Los Arroyos, $18^{\circ} 15^{\prime} \mathrm{N}, 71^{\circ} 45^{\prime} \mathrm{W}, 1680$ m, 17-18 July 1990, J. E. Rawlins, S. Thompson (1 female, CMNH); Dominican Republic: La Vega Prov., Cor- 
dillera Central, Loma Casabito, 15.8 km NW Bonao, 1902'12”N, 70³1’08”W, 1455 m, 28 May 2003, J. Rawlins, C. Young, R. Davidson, C. Nunez, P. Acevedo, evergreen cloud forest, east slope, UV light, sample 21312 (3 females, CMNH).

\section{Caribbomerus decoratus (Zayas)}

Figs 5e, 6, Table 1

Diagnosis. This species is recognized by the densely, coarsely punctate pronotum with a distinct (and sometimes paler), mostly impunctate median longitudinal callus surrounded by less distinct and mostly punctate peripheral calli (one on either side). Caribbomerus decoratus (Zayas) is very similar to C. picturatus (Napp and Martins) which is known only from Jamaica. In both species, the elytra have a vague, pale macula at the middle near the suture and have the elytral apices impunctate and pale. The leg color of C. decoratus ranges from uniformly pale yellow to reddish-brown with the clavate portions of the femora darker than the rest of the legs (in C. picturatus (Napp and Martins) the legs are uniformly pale yellow and much paler than the dorsum). Caribbomerus picturatus also can be distinguished from $C$. decoratus by the heavy surface sculpture and contiguous punctation of the frons, vertex, and antennal tubercles. In C. decoratus, the punctures are sparse and not contiguous.

Discussion. This species was described by Zayas (1975) from Cuba. His description of the pronotum and exposed terminal tergites, among many other features, suggests that the photograph of this species is mislabeled in Nearns et al. (2006). In that paper, figure 5a should be $C$. exiguus (Zayas) and figure 5 b should be $C$. decoratus (Zayas) (E. Nearns, pers. comm). This species, previously known only from Cuba (Zayas 1975; Monné and Bezark 2010), is now documented for the Dominican Republic (new island \& country record).

Specimens. Dominican Republic: Prov. Barahona, nr Filipinas, Larimar Mine 26 June -7 July 1992, Skillman, Skelley, Woodruff, blacklight (FSPC, donated to USNM); Dominican Republic: Barahona, vic. Filipinas, 1700', May 5-6 1985, E. Giesbert, coll (EFGC [FSCA]); Dominican Republic: Barahona, 2 km E. Payaso, 460 m, mv + bl, 13 July 1996, R. Turnbow (RHTC); Dominican Republic: Pedernales, Sierra Baoruco, 19 May 1992, R. Turnbow (RHTC).

\section{Caribbomerus asperatus (Fisher)}

Figs 5b, 6, Table 1

Diagnosis. Like $C$. attenuatus (Chevrolat) and $C$. similis (Fisher), $C$. asperatus has a very diagnostic rugulose pronotum that lacks calli and pubescence. It is recognized by a combination of features that include the matte finish on the elytra, micropunctation between elytral punctures, relatively uniform reddish-brown coloration above, distinctly elevated antennal tubercles, and elytral apices not distinctly impunctate. 


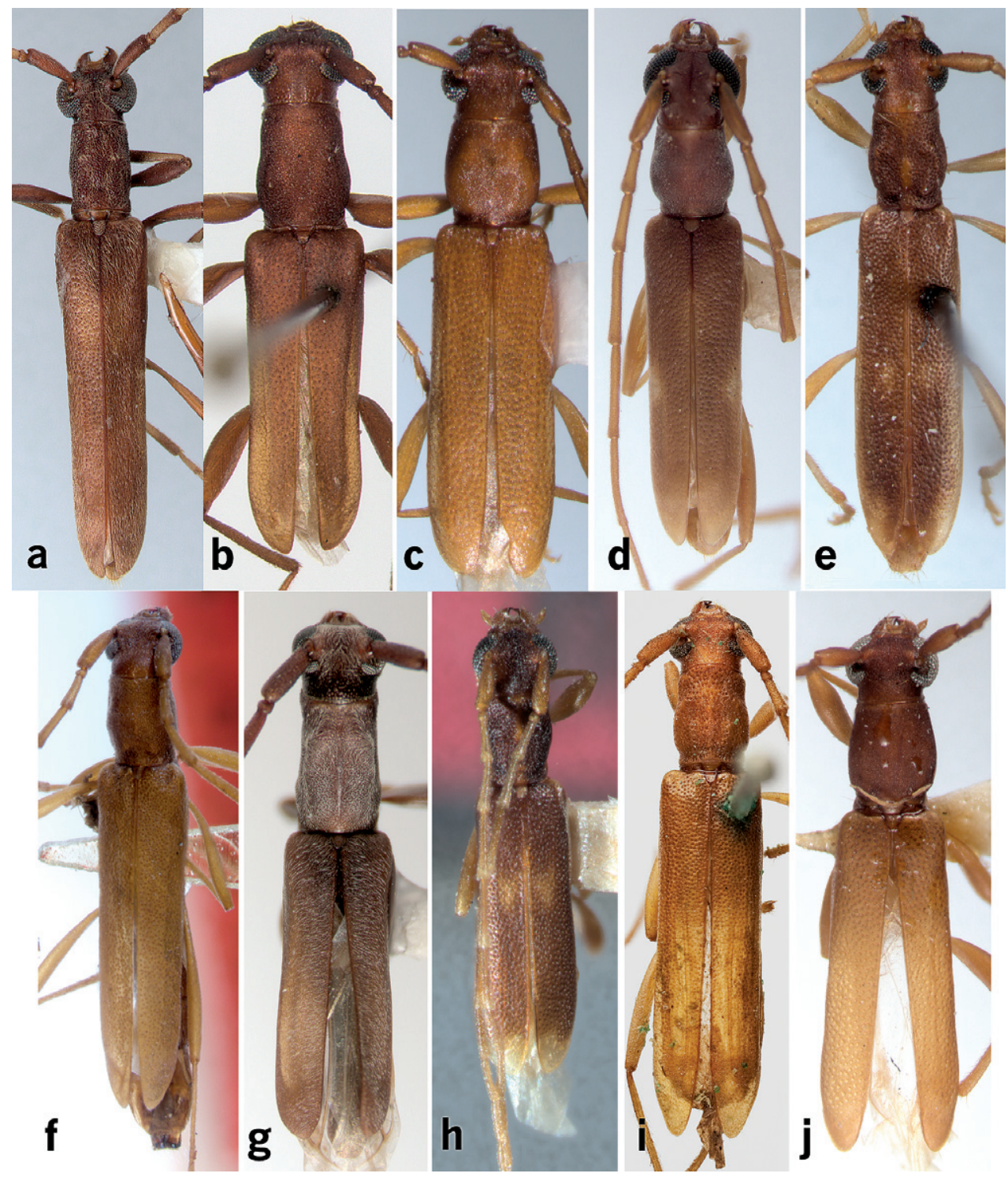

Figure 5. Dorsal habitus photographs of West Indian Caribbomerus species. a C. elongatus (Fisher) male b $C$. asperatus (Fisher) c C. attenuatus (Chevrolat) d C. charynae (Micheli) e C. decoratus (Zayas) f $C$. elongatus (Fisher) holotype female $\mathbf{g}$ C. exiguus (Zayas) h C. picturatus (Napp and Martins) i C. productus (White) j C. similis (Fisher).

Discussion. This is the most common species of Caribbomerus in Hispaniola. It was originally described based on specimens from Haiti, and has not been previously recorded from the Dominican Republic (Fisher 1932, Monné and Bezark 2010). With numerous collection records listed below, this species is now documented for the Dominican Republic (new country record). 


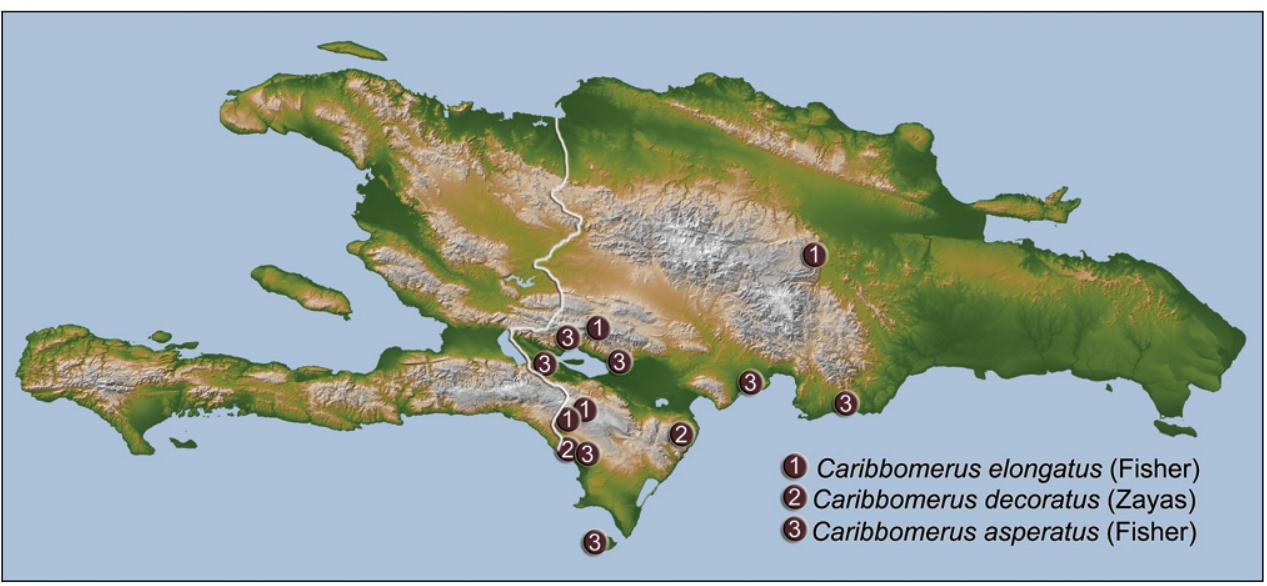

Figure 6. Distribution map for the three Caribbomerus species known from Hispaniola.

Specimens. Dominican Republic: Pedernales Prov., $12 \mathrm{~km} \mathrm{~N}$ of Cabo Rojo, $18^{\circ} 03^{\prime} \mathrm{N} 71^{\circ} 38^{\prime} \mathrm{W}, 250-350 \mathrm{~m}$, blacklight, 9 July 2004, Daniel Perez / Steve Lingafelter (5, USNM); Dominican Republic: Independencia Prov., $3 \mathrm{~km}$ up road from La Descubierta to Los Pinos, 15 July 2004, blacklighting, S. W. Lingafelter (4, USNM); Dominican Republic: Azua Prov., entrance to Boca Vieja Marina near Biyeya Beach, 23.iv.2004, $19^{\circ} 25^{\prime} \mathrm{N} 69^{\circ} 51^{\prime} \mathrm{W}, \mathrm{D}$. Perez, B. Hierro (night) RD\#241 (3, USNM); Dominican Republic: Pedernales Prov., Cabo Rojo, Alcoa (EFGC [FSCA]); Dominican Republic: Pedernales Prov., 10.2 km N Cabo Rojo (EFGC [FSCA]); Dominican Republic: Bahoruco, $5.8 \mathrm{~km} \mathrm{SW} \mathrm{Neiba,} \mathrm{eastern} \mathrm{playa} \mathrm{of} \mathrm{Lago} \mathrm{Enriquillo,} 3$ April 2004, collector: J. Rawlins, R. Davidson, C. Young (CMNH); Dominican Republic: Isla Beata, near Pedernales, October (MCZC); Dominican Republic: Bani, August (MCZC); Dominican Republic: Pedernales Prov., Cabo Rojo, sea level, 22 August 1988, beating veg., M. A. Ivie, T. K. Philips, \& K. A. Johnson colrs (WIBF); Dominican Republic: Independencia Prov., ESE Jimani, La Florida $18^{\circ} 24^{\prime} \mathrm{N}, 71^{\circ} 4^{\prime} \mathrm{W}, 20 \mathrm{~m}$, at uv light 14 April 1993, M. A. Ivie, D. Sikes, W. Lanier (WIBF); Dominican Republic: Pedernales, $9.5 \mathrm{~km}$ N. Cabo Rojo, $33 \mathrm{~m}, 18^{\circ} 00.042^{\prime} \mathrm{N}, 71^{\circ} 38.793^{\prime} \mathrm{W}, 08$ August 1999, lights and beating, M. A. Ivie, and K. A. Guerrero (WIBF).

\section{Caribbomerus similis (Fisher)}

Figs 5j, Table 1

Diagnosis. Like C. attenuatus (Chevrolat) and C. asperatus (Fisher), C. similis (Fisher), has a rugulose pronotum that lacks calli and pubescence. It is distinguished from $C$. asperatus by having the integument mostly light reddish-brown in color with the elytra distinctly paler than the pronotum, having the antennal tubercles unelevated, and in 
having the elytral apices distinctly impunctate. It is distinguished from $C$. attenuatus in having a matte integument with micropunctation between punctures.

Discussion. This is an uncommonly collected species. It was originally described from two specimens from Antigua (Fisher 1932). Monné and Bezark (2010) record it from Barbuda. One specimen was examined in the USNM from Dominica and this is a new country record.

Specimens. Dominica: Grande Savane, February 3, 1965, J. F., G. C., and T. M. Clarke (USNM).

\section{Key to Caribbomerus of the West Indies}

1 Pronotum with impunctate, non-rugulose, or non-asperate median callus .. 2

- Pronotum without impunctate, non-rugulose, or non-asperate median cal-

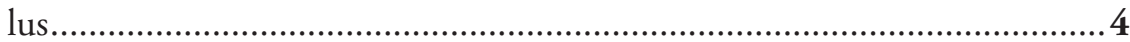

2(1) Elytra with pale spot near suture at middle ........................................

- $\quad$ Elytra nearly uniformly colored, without pale spot at suture near middle. Cuba, Hispaniola................................................... elongatus (Figs 1-4)

3(2) Frons, vertex, and antennal tubercles with dense, contiguous punctation. Jamaica .......................................................... picturatus (Fig. 5h)

- $\quad$ Frons, vertex, and antennal tubercles with sparse punctation. Cuba, Hispaniola

4(1) Pronotum with distinct punctures ................................................5

- $\quad$ Pronotum without distinct punctures (either asperate or rugulose) ............6

5(4) Pronotum with dense, contiguous punctures throughout. Scutellum with distinct pubescence joining together at sides, apex, and middle as in Fig. 3a. Cuba, Hispaniola....

elongatus (Figs 1-4)

- $\quad$ Pronotum with punctures mostly separated by at least their diameter. Scutellum glabrous or with reduced pubescence (not as in Fig. 3a). Jamaica.....

productus (Fig. 5i)

6(4) Pronotum coated with sparse, fine pubescence .................................... 7

- Pronotum glabrous ...................................................................... 8

7(6) Pronotum much longer than wide (at least $1.5 \times$ width) with a narrow strip at middle that is devoid of pubescence; microsculptured and rugulose, but lacking asperites. Cuba. exiguus (Fig. 5g)

- $\quad$ Pronotum only little longer than wide (about $1.1 \times$ width) without a narrow strip at middle that is devoid of pubescence; not microsculptured or rugulose, but with distinct asperites. Puerto Rico charynae (Fig. 5d)

8(6) Elytra with matte integument; with micropunctation between punctures ...9 Elytra with glossy integument; without micropunctation between punctures. Cuba, Puerto Rico, Bahamas attenuatus (Fig. 5c) 
9(8) Light reddish-brown in color with elytra distinctly paler than pronotum; elytral apices distinctly impunctate; antennal tubercles not elevated, without noticeable depression between. Antigua, Barbuda, Dominica..... similis (Fig. 5j)

- $\quad$ Darker reddish-brown in color with elytra usually no lighter than pronotum; elytral apices not distinctly impunctate; antennal tubercles elevated with distinct depression between them. Hispaniola

asperatus (Fig. 5b)

\section{Acknowledgments}

Many thanks to the curators and caretakers of the collections above, especially to Michael Ivie (WIBF), Michael Thomas (FSCA), Paul Skelley (FSCA), Robert Turnbow, Jr. (RHTC), Frederick Skillman (FSPC), John Rawlins (CMNH), Robert Davidson $(\mathrm{CMNH})$, Bob Androw $(\mathrm{CMNH})$, Sharon Shute $(\mathrm{BMNH})$, Serge Laplante $(\mathrm{CNCI})$, and the late Edmund Giesbert (EFGC). I thank Harry Taylor for photographing the type of Merostenus productus from the BMNH. For my trip in 2004, I thank Daniel Perez (USNM) and for my trips in 2005, 2006, and 2010, I thank Kelvin Guerrero (Santo Domingo Este) for their aid in logistics and obtaining permits. Finally, I thank the Subsecretaria de Áreas Protegidas y Biodiversidad de la Secretaría de Estado de Medio Ambiente y Recursos Naturales, Dominican Republic for providing the collecting and export permits (2004 collecting permit \#0908 and export permit \#0597; 2005 collecting permit \#0876 and export permit \#0403; 2006 collecting permit \#01140 and export permit \#0953).

\section{References}

AMNH (2010) American Museum of Natural History Online Type Database. http://www. research.amnh.org/invertzoo/types_db/ [accessed October 12, 2010]

Chalumeau F, Touroult J (2005) Les Longicornes des Petites Antilles (Coleoptera, Cerambycidae) Taxonomie, Ethologie, Biogeographie. Pensoft Series Faunistica 51: 241 pp.

Fisher WS (1932) New West Indian cerambycid beetles. Proceedings of the United States National Museum 80(2922) Art. 22: 1-93.

Lingafelter SW, Monné MA, Nearns EH (2010) Online Image Database of Cerambycidae Primary Types of the Smithsonian Institution. Available from: http://www.elaphidion.com/ [accessed October 12, 2010]

Martins UR, Galileo MHM (2005) Tribo Graciliini. In: Cerambycidae Sul-Americanos. Taxonomia, Vol. 5: Subfamília Cerambycinae: Cerambycini - Subtribo Sphallotrichina subtrib. nov., Callidiopini Lacordaire, 1869, Graciliini Mulsant, 1839, Neocorini trib. nov. Sociedade Brasileira de Entomologia, São Paulo, 223-238 .

MCZC (2010) Museum of Comparative Zoology, Harvard University, Database of Images of Primary Types. http://insects.oeb.harvard.edu/mcz/index.htm [accessed October 12, 2010] 
Micheli J (2003) New longhorn beetles from Puerto Rico (West Indies). The Coleopterists Bulletin 57(2): 191-204.

Monné MA, Bezark LG (2010) Checklist of the Cerambycidae, or longhorned beetles (Coleoptera) of the Western Hemisphere. http://plant.cdfa.ca.gov/byciddb/documents.html [Accessed February 11, 2011]

Napp DS, Martins UR (1984) Notas e descriçôes em Callidiopini (Coleoptera, Cerambycidae). Revista Brasileira de Entomologia 28(1): 51-58.

Nearns EH, Branham MA, Bybee SM (2006) Cerambycidae (Coleoptera) types of the Fernando de Zayas Collection, Havana, Cuba. Zootaxa 1270: 1-17.

Perez-Gelabert DE (2008) Arthropods of Hispaniola (Dominican Republic and Haiti): A checklist and bibliography. Zootaxa 1831: 1-530.

Vitali F, Rezbanyai-Reser L (2003) Beiträge zur insektenfauna von Jamaika, Westindien (Karabik) 5. Bockkäfer, Teil I (Coleoptera, Cerambycidae). Les Cahiers Magellanes No. 26: $1-16$.

Zayas F (1975) Revisión de la familia Cerambycidae (Coleoptera, Phytophagoidea). Academia de Ciencias de Cuba, Instituto de Zoología, La Habana, Cuba: 443 pp. 
